\title{
Effect of Conceptual Knowledge of Student Science on Student Learning Outcomes using STAD Type Cooperative Model
}

\author{
Emha Fidiyan Akhadi $^{1^{*}}$, Yusnadi ${ }^{2}$, Mara Bangun Harahap ${ }^{3}$ \\ ${ }^{1}$ Student of Postgraduate Basic Education, State University of Medan, Medan, Indonesia \\ ${ }^{2,3}$ Lecturer of Postgraduate Basic Education, State University of Medan, Indonesia
}

*Corresponding Author: Emha Fidiyan Akhadi, Student of Postgraduate Basic Education, State University of Medan, Medan, Indonesia

\begin{abstract}
This study aims to analyze the difference between science conceptual knowledge of class students who are given the STAD type cooperative learning model compared to students who study with conventional models. This type of research is experimental research. The population in this study was 217 students. The sampling technique is done by purposive sampling class. The number of samples taken was 60 students divided into control class and experimental class. The experimental class was given learning treatment with the STAD type model and the control class was given conventional learning treatment. Data collection techniques were performed using conceptual knowledge tests and motivation questionnaires for learning data analysis techniques using two-way Anava. The results of this study indicate that the learning outcomes of science students who are taught with STAD type learning models differ significantly and are better than students who are taught by conventional learning
\end{abstract}

Keywords: Conceptual Knowledge, STAD Type, Students

\section{INTRODUCTION}

Education for Indonesian citizens is very important, so that they can produce competent and reliable human resources so that their citizens can live properly, be able to compete with other countries and advance the Indonesian economy amidst the current global economic instability in Indonesia, and are expected to produce resources competent human power. Therefore the government should start from the education sector where prospective generations of competent human resources are born from education, especially in primary schools. One effort to improve the quality of education is to change the educational paradigm, especially in elementary schools (SD) from learning that only relies on teachers as learning resources into student-centered learning. This requires each teacher to be more creative in developing learning so as to enable students to excel through real activities that are fun and able to develop their potential optimally. Likewise the case with science learning requires teacher creativity.

Based on research published in educational journals suggests that there are differences between the acquisition of significant learning outcomes between the STAD type cooperative learning model and classical learning. The STAD type cooperative learning model is superior to classical learning in influencing student learning outcomes published in the international education research journal entitled "The impact of motivation on learning of secondary school students in karachi; an analytical study (International journal academic social science) ". Based on the results of his research suggests that teachers need to understand student psychology. The teacher uses teaching methods according to interests, age and content. Because teaching methods can foster student motivation to learn. With the motivation of the students of course they try to achieve learning goals [1]. Parna's research results showthat the motivation and learning outcomes of students who learn with STAD type cooperative learning are significantly better than students who take learning with conventional models [2]. In line with the explanation by Astrawan that the learning motivation of students who take the STAD learning model differs significantly from students who take conventional learning and there is a significant difference in the learning achievement of students who take STAD learning with students who take conventional learning [3]. 
In the process of learning science learning media is very important to help motivate students in understanding the concepts of the lessons given by the teacher. Besides that, the practical equipment or the Natural Science KIT is also very much needed to help students to more easily understand the subject matter of Natural Sciences that not only understand the concepts.

The importance of learning media is because learning media carries and evokes student motivation, joy and joy for students, renewing their enthusiasm, helping to establish knowledge in the minds of students and living learning. According to Sari that cooperative learning (Cooperative learning) is a series of learning activities where students learn and work in small groups (small teams) collaboratively consisting of 4 to 6 students with heterogeneous academic abilities so as to stimulate students more passionate in learning to achieve goals learning that has been formulated [4]. Furthermore Nurdiansyah said that the conventional learning model is a traditional learning model or also called lecture, because this strategy has long been used as an oral communication tool between teachers and students in the teaching and learning process. In conventional science learning strategies (lectures) do not provide opportunities for students to be active in learning so students tend to just be quiet and listen to the teacher's explanation.

Based on the explanation above, through this study a learning process plan will be designed that can increase student motivation and learning outcomes through the application of cooperative learning models of student team Achievement Division (STAD) types. For the learning process to be effective it needs to involve strong learning motivation, or high learning motivation. Motivation is one of the psychological aspects that drives individuals to choose, carry out, and direct their activities. [5]

Conceptual knowledge will be achieved well by students determined by the activities of the teacher, students and teaching and learning activities in the classroom. The cooperative learning model can help students learn in groups, interact with other students and learn from one another but students must also learn individually. Thus, students will be active in their respective groups, in addition to this learning model the teacher will know how student cooperation in solving a problem in a group.

To increase students' conceptual knowledge of science, teachers must pay attention to each component of learning, choose learning models, teaching aids, and approaches and evaluations of learning that must be done appropriately. To involve students' activeness and intellectual optimally in science learning, a learning model that can activate and directly involve students in learning is needed. The student team achievement division model that is done in groups requires students to have good teamwork in improving students' thinking skills. The cooperation obtained in the group members will provide good conceptual learning knowledge. In this student team achievement division cooperative model there will be students who have high learning motivation and low learning motivation.

The stronger a person's motivation, the more likely he is to carry out an activity or task. Lack of motivation also affects the low conceptual knowledge of students that can be known through the test scores and the value of student report cards. This can be seen from the acquisition of the average value of Natural Sciences, especially class IV SDIT Hj. Mardiyah Lubis is only 65 so that it has not yet reached the KKM set by the school with a value of 75. Motivation and learning strategies have an important role in the learning process. Knowledge concept or learning outcomes achieved by students can be influenced by several factors, both those that originate from students (internal factors) namely motivation that grows from students because of their desires and factors that come from outside students (external factors) that is motivation that grows because you want something in the form of objects, praise and others.

Based on the description above, the researcher views the need to conduct this research to prove that the cooperative learning model of student team achievement division (STAD) and conventional learning models combined with learning motivation can improve students' conceptual knowledge of science. This is because students who experience learning with a cooperative model will feel that the learning they experience is very interesting, meaningful, and enjoyable. With interesting cooperative learning activities will arouse student learning motivation so that they are encouraged and interested in doing all the series of learning activities carried out and students will feel happy to look for and solve problems in the test questions given by the teacher. 


\section{MATERIALS \&MethodS}

\subsection{Research Design}

This design used in this study is a quasi-experimental. (quasi-experimental), which aims to determine whether there is a result of "something" imposed on the subject of students, namely students. This study involved two sample classes that were given different treatments. In the experimental class given the treatment of cooperative learning models. Whereas in the control class given the "natural" treatment that is usually done by schools with conventional learning models. The design of this research is in the form of Two Group Pre-test Post-test Design. At the end of the experiment both groups were tested with the same measuring instrument and became experimental data.

\subsection{Study Samples}

Population is a generalization area that consists of objects / subjects that have certain qualities and characteristics determined by researchers to be studied and then drawn conclusions. Based on the statement, the population in this study were students of SDIT Hj. Mardiyah Lubis 2016/2017 Academic Year consisting of 12 classes with a total of 217 students. Class division is not based on rank, so there are no superior classes with different characteristics. This was chosen so as to reduce the bias towards research results. Besides that, the sample is part of the number and characteristics possessed by the population. The sampling technique used was cluster random sampling (random sample) of two classes of samples [6]. There are two classes selected as research samples namely class IV (A) referred to as the experimental class taught by the cooperative learning model type student team achievement division (STAD), then class IV (B) is called the control class taught by conventional strategies. This technique was chosen because what was sampled was the number of classes not the number of students in the population, so that class IV SDIT Hj was obtained. Mardiyah Lubis as a research sample, with the provisions of one class using the STAD type cooperative learning model and one class with conventional learning strategies. Before conducting research on previous students students are given a learning motivation questionnaire to find out students who have high learning motivation and low learning motivation.

\subsection{Instruments}

In this study the student's learning achievement test instrument was first tested to find out the validity, reliability, difficulty index and different power level of the questions. The procedure for conducting the feasibility test on student learning outcomes is: (1) the determination of the respondents to test the instrument; (2) instrument trials; and (3) instrument analysis. The respondents used as trial instruments were taken from outside the sample which is equivalent to the research sample. The form of analysis of the trial of this instrument uses the Microsoft Office Excell 2007 software program. The validity of the student learning outcomes test is done by correlating the item scores and the total scores. The formula used to measure the validity of these learning outcomes tests uses product moment correlation [7] namely:

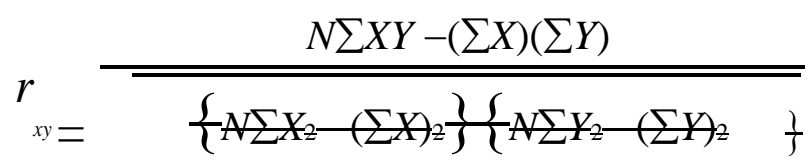

\section{RESULTS \&DISCUSSION}

\subsection{Result}

\section{- Pretest Data Results of Conceptual Knowledge Learning}

Testing the data requirements for the experimental and control class pretest data is carried out by tests of normality and homogeneity so that they can see the difference between the results of the two class samples.

Table1: Pre Test Data Class IV Konvensional Model and STAD Model

\begin{tabular}{|c|c|c|c|c|c|}
\hline \multicolumn{3}{|c|}{ Control Class } & \multicolumn{3}{|c|}{ Experiment Class } \\
\hline Score & $\mathbf{F}$ & F relatif & Score & $\mathbf{F}$ & f relatif \\
\hline $67-70$ & 2 & 6,66 & $67-70$ & 0 & 0 \\
\hline $71-75$ & 12 & 40 & $71-75$ & 1 & 3,33 \\
\hline
\end{tabular}


Effect of Conceptual Knowledge of Student Science on Student Learning Outcomes using STAD Type Cooperative Model

\begin{tabular}{|c|c|c|c|c|c|}
\hline $76-80$ & 8 & 26,66 & $76-80$ & 8 & 26,66 \\
\hline $81-85$ & 7 & 23,33 & $81-85$ & 15 & 50 \\
\hline $86-90$ & 1 & 3,33 & $86-90$ & 6 & 20 \\
\hline $91-95$ & - & - & $91-95$ & 0 & 0 \\
\hline 96-100 & - & - & 96-100 & 0 & 0 \\
\hline Total & 30 & $100 \%$ & Total & 30 & $100 \%$ \\
\hline Mean & 76,3 & & Mean & 82,4 & \\
\hline
\end{tabular}

Based on Table 1.above it is obtained that the pre-test results of the control class students have an average of 76.3. While the experimental class had an average of 86.4. From these data it can be concluded that there are differences in the average value of the pretest of the control class and the experimental class, it can be seen more clearly in the appendix. So that later research data can be analyzed using parametric tests, it is necessary to do some assumption tests or prerequisite tests. The first requirement that data can be tested parametrically is the normality test. Normality test aims to see the distribution of student learning outcomes data in both sample classes are normally distributed or not. Table 2.shows the results of the normality test using the Kolmogrov-Smirnov test with the help of SPSS 21.0.

Table2: Normality Test Data Pre Test Class Control and Experiments Pre Test Normality Analysis Results

\begin{tabular}{|l|l|l|l|l|}
\hline \multicolumn{1}{|c|}{ Variable } & \multicolumn{1}{|c|}{ Sig. } & \multicolumn{1}{c|}{ A } & \multicolumn{1}{c|}{ Information } \\
\hline Control Class & 30 & 0,899 & 0,05 & Normal Distribution \\
\hline Exsperiment Class & 30 & 0,712 & 0,05 & Normal Distribution \\
\hline
\end{tabular}

Source: Data Fields, 2018

The normality test in the control and experimental class in Table 2 above was obtained from the Kolmogrov-Smirnov normality test. Based on the results of the analysis obtained by sig. the control class and the experimental class with $\alpha(5 \%)$ respectively the control class by 0.899 and the experimental class by 0.712 . This means that significance> 0.05 concluded that all classes are normally distributed or the distribution of population data is not different from the distribution of normal data, the two research data variables are normally distributed, then statistical tests can be performed, namely parametric statistical tests. The results of the analysis of the normality of the stage data are in Appendix 1. From the results of the normality test it can be concluded that the two samples are normally distributed and the histogram of the normal distribution for the two sample classes can be seen in Figures 1 and 2 below.
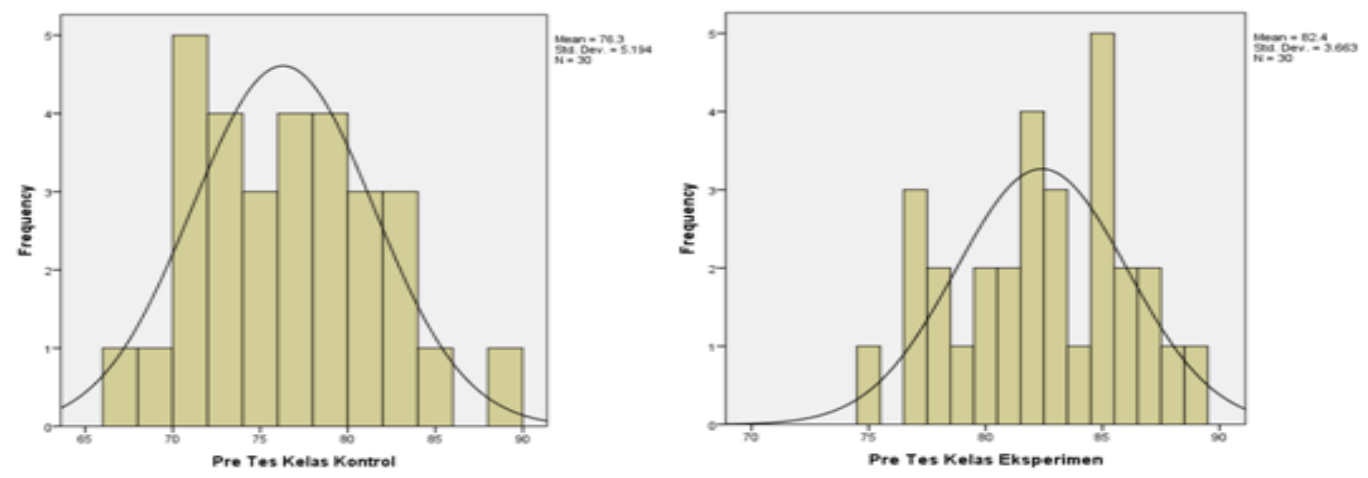

Figure1, 2: Histogram Normal Distribution Control Class and Experiment Class

From Figure 4.1.and figure 4.2. above, it can be seen that the distribution histogram for the control class and experimental class is normally distributed. After the data is known to be normally distributed, it is then determined whether the two sample classes have the same variance. Test the similarity of variance and the mean pretest value is done by the Test of Homogenity of Variance using SPSS 21.0 which is presented in Table 3. below below:

Table3: Homogenity Test Data Pre test

\begin{tabular}{|c|c|c|c|c|}
\hline \multicolumn{5}{|c|}{ Test of Homogeneity of Variances } \\
\hline Levene Statistic & df1 & df2 & Sig. \\
\hline .000 & 1 & & 57 & .048 \\
\hline
\end{tabular}


The test results show the value of Fcount for pretest conceptual knowledge 0.000 with a significance of 0.048 ( $\mathrm{F}$ table $=4.01, \alpha=0.05$ ). This data shows that from the homogeneity test of variance obtained Fcount (0.000) < Ftable (4.01), so it can be concluded that the conceptual knowledge of the control class and the experimental class have the same or homogeneous variance. Both classes are normally distributed and have a homogeneous variance, then a similarity test of two averages with a two-party t-test through the help of the SPSS 21.0 for Windows program uses Independent Sample TTest with the assumption that both homogeneous variances (equal variance assumed) with a significance level of 0.5 . The results of the t-test are shown in table 4. below.

Table4: T-Test Pretest Control Class and Experiment Class Independent Samples Test

\begin{tabular}{|c|c|c|c|c|c|c|c|c|c|c|}
\hline & \multicolumn{2}{|c|}{\begin{tabular}{|c|} 
Levene's Test \\
for Equality of \\
Variances \\
\end{tabular}} & \multicolumn{7}{|c|}{ Levene's Test for Equality of Variances } \\
\hline & & \multirow[t]{3}{*}{$\mathrm{F}$} & \multirow{3}{*}{ Sig. } & \multirow[t]{3}{*}{ T } & \multirow[t]{3}{*}{ df } & \multicolumn{2}{|c|}{ Sig. (2-Mean } & \multicolumn{3}{|c|}{ 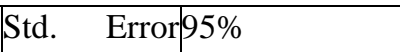 } \\
\hline & & & & & & tailed) & Difference & Difference & $\begin{array}{l}\text { Confide } \\
\text { Interval } \\
\text { Differe } \\
\end{array}$ & $\begin{array}{l}\text { of } \\
\text { of the } \\
\text { nce }\end{array}$ \\
\hline & & & & & & & & & Lower & Upper \\
\hline \multirow[t]{2}{*}{$\begin{array}{l}\text { Pengetahuan } \\
\text { Konseptual }\end{array}$} & $\mid \begin{array}{l}\text { Equal } \\
\text { variances } \\
\text { assumed }\end{array}$ & 4.074 & .048 & -5.263 & 57 & .000 & -6.193 & 1.177 & -8.550 & -3.837 \\
\hline & \begin{tabular}{|l|} 
Equal \\
variances \\
not \\
assumed \\
\end{tabular} & & & -5.231 & 49.834 & .000 & -6.193 & 1.184 & -8.571 & -3.815 \\
\hline
\end{tabular}

Table 4 shows that the significance value (Sig.2-tailed) with the t-test is 0.048 . Because the significance value is greater than $0.05, \mathrm{H} 0$ is accepted or the students' conceptual knowledge at the beginning (pretest) of the two classes is not significantly different. So in the absence of differences in the initial abilities of students between the experimental class and the control class. After the raw data of the research results are obtained, the next stage is an analysis of these observations. Initial analysis conducted on the results of students' conceptual knowledge research is to see the comparison of pretest and post-test data in the control and experimental classes. Figure 4.3 shows a comparison of the high-level thinking skills of students in the control and experimental classes.

Based on Figure 3 can be seen an increase in the average conceptual knowledge of students before and after being given treatment. The control class decreased by 3 , due to the control class was not given treatment with the use of the learning model when the teaching and learning process took place, while the experimental class experienced an increase of 3.24. Then it can be concluded that the increase in conceptual knowledge of students who are taught with the STAD model is better than the control class that is taught with the conventional model.

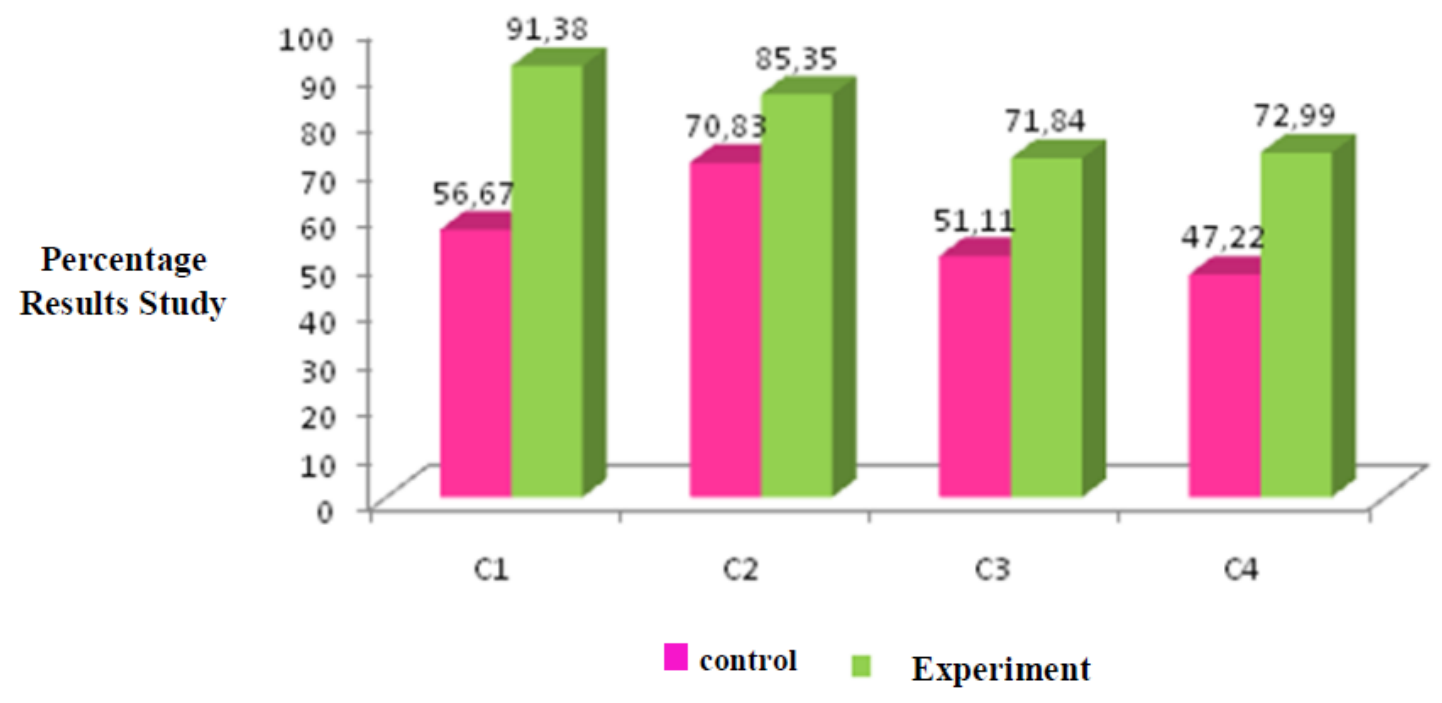

Figure3: Diagram Achievement of Conceptual Knowledge According to Cognitive LevelC $C_{1}, C_{2}, C_{3}, C_{4}$ 
From the diagram above, we can see that the learning outcomes obtained in the experimental class have also been increased changes in each level of the cognitive domain, but the most significant increase in the cognitive domains in $\mathrm{C} 1$ and $\mathrm{C} 4$ levels.

\subsection{Discussion}

Based on the results of research conducted by students who were given learning by using the STAD learning model, the average conceptual knowledge of students was higher compared to students who were given learning with conventional learning models. The results of the study stated that the STAD learning model was significantly more effective in being able to improve student learning outcomes compared to conventional learning. Besides that it can enhance students' conceptual knowledge, STAD learning models can also effectively increase student learning motivation.

Learning by using the STAD learning model emphasizes the process of active student involvement in discovering the material themselves and connecting it with the environment so that it encourages students to be able to apply it in their daily lives. This STAD learning model not only makes students act as verbal recipients of the material, but also plays a role in finding and formulating their own core of the material provided, but it emphasizes more that students are ready to help and guide other group friends in finding learning concepts, where friends who have not finished by themselves asking for help from friends who have finished doing the task. The STAD learning model encourages students to be more active in learning so students will get a better understanding of the material and will be more interested in the material presented. The STAD learning model seeks to instill the basics of scientific thinking in students because in the learning process students learn more by themselves, causing students to be more active and creative in solving problems. The STAD learning model is also able to make students work together through group discussions that require students to provide input to other students so that students who are less capable become more motivated in learning material that is poorly understood.

Another case with conventional models that have been widely used in the classroom and learning activities tend to be teacher-centered learning. The science learning activities that take place are only the transfer of knowledge from the teacher to students. This causes students to lack an active role in the process and construction of knowledge in themselves. In conventional models students tend to only memorize facts and concepts without knowing how the facts and concepts are formed. Conceptual knowledge that is based on high motivation will be active if students of all ages experience other problems such as doubts, or questions. This motivation encourages sustainable growth and other knowledge. This ability to work together optimally will emerge through the syntax of the STAD model. This is part of the process of improving the current learning system.

In addition, processing implies valuing. Through group processing can be identified from the sequence or stages of group activities and the activities of group members. Who among the group members is very helpful and who is not helping. The purpose of group processing is to increase the effectiveness of members in contributing to collaborative activities to achieve group goals. In line with Nurdiansyah's opinion that the STAD cooperative learning taught are special skills so that they can work well together in their groups, such as being good listeners, students are given an activity sheet containing questions or tasks planned to be taught. During group work, the task of group members is to achieve completeness.

In addition, other research conducted by Astrawan shows that there are significant differences in science learning outcomes between students who take learning with contextual learning models and students who take learning with conventional learning models. The contextual learning model is 17.15 greater than the average learning outcomes of natural science groups of students who take learning with conventional learning models of 5.40. Significant differences indicate that learning using contextual learning models has an effect on student learning outcomes in science compared to conventional learning models.

\section{CONCLUSION}

Based on the results of research and discussion, it can be concluded that the conceptual knowledge of students with the STAD type cooperative learning model is better than the conceptual knowledge of students with conventional learning models, where the average conceptual knowledge of students in 
the experimental class 85.66 while in the control class is 73.43 .

\section{REFERENCES}

[1] Djamarah, B.S.2011. Learning Psychology. Jakarta : RinekaCiptaMuhlis, (2018), Pengaruh Model Pembelajaran Kooperatif Terhadap Motivasi dan Hasil Belajar Siswa Pada Materi Sistem Koloid SMAN 4 Bantimurung Maros, Jurnal PEMBELAJAR: Jurnal Ilmu Pendidikan, Keguruan, dan Pembelajaran Volume 2 Nomor 1

[2] Parna, I Ketut,dkk, 2015. Pengaruh Model Pembelajaran Kooperatif Tipe Stad Terhadap Motivasi Berprestasi Dan hasil Belajar IPA Siswa Kelas V Sd Gugus VII Kecamatan Kubu Tahun Pelajaran 2014/2015, e- Journal Program Pascasarjana Universitas Pendidikan Ganesha Program Studi Pendidikan Dasar, Volume 5, No. 1

[3] Astrawan,J., dkk. Pengaruh Model Pembelajaran Kooperatif Tipe Student Team Achievement Division Terhadap Motivasi Belajar Dan Hasil Belajar IPA, e-Journal Program Pascasarjana Universitas Pendidikan Ganesha Jurusan Pendidikan Dasar Volume 3 No. 2

[4] Sari, U. 2018. Pengaruh Model Pembelajaran Kooperatif Tipe Stad (Student Teams Achievement Division) Terhadap Pemahaman Konsep Siswa Kelas X Pada Mata Pelajaran Biologi Di Sma Setia Darma Palembang, E-Journal Universitas Islam Raden Fatah Palembang

[5] Nurdiansyah, W dan Budhi W., 2016. Pengaruh Model Pembelajaran Stad (Student Teams Achievement Deviasion) Terhadap Prestasi Belajar Fisika Kelas VIII. Jurnal Ilmiah pendidikan Fisika-COMPTO, Volume 4 No.1

[6] Sugiyono. 2011. Metode Penelitian Kuantitatif, Kualitatif dan R\&D. Bandung: Afabeta

[7] Arikunto, 2011, Evaluasi Hasil Belajar: Jakarta: Pustaka Pelajar

\section{AUTHORS' BIOGRAPHY}

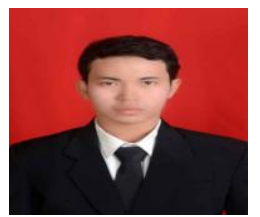

Emha Fidiyan Akhadi, is a Basic Education Postgraduate student at Postgraduate Program of Universitas Negeri Medan (State University of Medan), Medan, North Sumatera, Post code 20221, Indonesia.

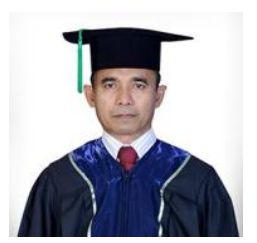

Ptof. Dr. Yusnadi, M.S, is a Lecturer at Graduate and Postgraduate Program of Universitas Negeri Medan (State University of Medan), Medan, North Sumatera, Post code 20221, Indonesia.

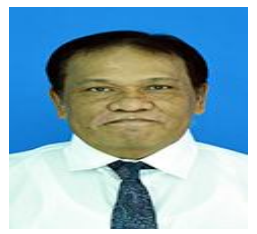

Prof. Dr. Mara Bangun Harahap, M.S, is a Lecturer at Graduate and Postgraduate Program of Universitas Negeri Medan (State University of Medan), Medan, North Sumatera, Post code 20221, Indonesia.

Citation: Emha Fidiyan Akhadi, Yusnadi, et.al. "Effect of Conceptual Knowledge of Student Science on Student Learning Outcomes using STAD Type Cooperative Model". International Journal of Humanities Social Sciences and Education (IJHSSE), vol. 6, no.9, 2019, pp. 94-100. doi: http://dx. doi.org/10.20431/23490381.0609010.

Copyright: () 2019 Authors. This is an open-access article distributed under the terms of the Creative Commons Attribution License, which permits unrestricted use, distribution, and reproduction in any medium, provided the original author and source are credited. 